\title{
Study on the Effects of the Performance of Thematic Tourism Listed Companies on Voluntary Information Disclosure
}

\author{
Liqing Lin \\ School of Economics and Commerce, South China University of Technology, Guangzhou, China \\ Email:liq_Lin@163.com
}

How to cite this paper: Lin, L.Q. (2017) Study on the Effects of the Performance of Thematic Tourism Listed Companies on Voluntary Information Disclosure. Journal of Service Science and Management, 10, 465-481.

https://doi.org/10.4236/jssm.2017.106037

Received: October 30, 2017

Accepted: November 14, 2017

Published: November 17, 2017

Copyright $\odot 2017$ by author and Scientific Research Publishing Inc. This work is licensed under the Creative Commons Attribution International License (CC BY 4.0).

http://creativecommons.org/licenses/by/4.0/

\begin{abstract}
Based on the review of the relevant theory and empirical research of listed tourism companies' voluntary information disclosure and performance. This paper selects 11 thematic tourism listed companies in Shanghai and Shenzhen Stock Exchange as the research samples, and applies empirical analysis to discuss the relationship between voluntary information disclosure and corporate performance of thematic tourism listed companies. The results show that: the overall level of voluntary information disclosure in China's thematic tourism companies is moderate, and shows the trend of increasing year by year; The Return on Equity, Turnover of Total Assets and the Operating Income Growth Rate are positively related to the disclosure of voluntary information, and the Debt to Asset Ratio is negatively related to the disclosure of voluntary information.
\end{abstract}

\section{Keywords}

Thematic Tourism Listed Companies, Voluntary Information Disclosure, Corporate Performance

\section{Introduction}

With the sustained and rapid development of national economy, people's living standard is increasing day by day, the growth of the tourism industry will usher in rapid, tourism listed companies as the active plate on the stock market also attract more and more attention. The competition of capital market, forcing outside the mandatory disclosure of information of listed companies, will take the way of voluntary disclosure more reliable information to attract investors, so as to get more capital. The research on voluntary information disclosure of listed 
companies has attracted more and more attention from scholars at home and abroad. But at home and abroad, few of tourism research mainly focused on the performance evaluation of listed companies, and the diversification, capital structure is involved, for less information disclosure research of tourism industry, especially the listed tourism companies voluntary information disclosure and the results of empirical research is less.

Tourism as the strategic pillar industry of national economy, set by the state council is in rapid development period, tourism as a modern service industry bibcock, will become one of the strategic pillar industry of the third industry rapid development. Theme class tourism listed companies as the flagship your community need better corporate governance in order to promote the rapid, healthy and sustainable development, the researches on the correlation between information disclosure and performance has a certain theoretical value and important practical significance, and voluntary information disclosure of listed companies can not only enrich tourism research system, the theory research results can also strengthen the voluntary information disclosure of listed companies of the guiding theme class tourism, promoting the sustainable development of the company and the healthy development of capital market.

\section{Literature Review}

\subsection{Voluntary Information Disclosure}

Information disclosure of listed companies is divided into mandatory information disclosure and voluntary disclosure. The so-called mandatory information disclosure refers to the information that is required to be disclosed by the listed companies specified by laws and regulations such as company law, securities law, accounting standards and regulations. Meek, Roberts and Gray (1995) argues that voluntary disclosure of information refer to the mandatory disclosure of information disclosure, on behalf of the company, the management information for part of the operation and management condition of independent choice (disclosure), its purpose is to provide thought and decision-making related to financial information users and information such as company development [1]. In 2001 the United States financial accounting standards board (FASB) in the improvement enterprise report: to promote the voluntary disclosure of insight report to the voluntary disclosure of information to define the definition of a more professional: active disclosure of listed companies, rather than generally accepted accounting principles and the securities regulatory departments clear requirements of information outside the basic financial information [2]. In recent years, the company voluntary information disclosure has caused extensive concern of accounting profession in our country, especially in the Shenzhen stock exchange issued in October 2003, the Shenzhen stock exchange listed companies investor relations management guidelines in the first introduced the concept of voluntary information disclosure, namely: the listed company through different 
kinds of activities and investor relations management, voluntarily disclosed under current laws, regulations and rules shall make disclosure of information outside of the information [3].

\subsection{Theoretical Basis of Voluntary Information Disclosure}

The theoretical formation of voluntary disclosure of listed companies originates from agency theory (Jensen, Mecking) [4], signal transmission theory (Stephen, Ross) [5] and information asymmetry theory (Akerlof [6], Spence [7], Stiglitz).

\subsubsection{Agency Theory}

The most basic characteristic of modern enterprise system is the separation of ownership and control of the company, and the principal-agent relationship is formed between shareholders and operators. Under this relationship, because the two goals conflict, agents tend to use of the information advantage to maximize their own interests, the principal to enter into a contract with the agent to reduce this kind of conflict, asked the agent to the principal's interests for the purpose of management. According to agency theory, the principal agent in order to limit the pursuit of additional benefits, maximize the agent's behavior in line with their own utility will sign a series of contract with the agent, the agent's long-term interests is closely related to the growth of the company's market value. However, because the supervision agent has to pay the cost, the client will take the action of reducing the agent's remuneration to compensate for this loss. Agent, therefore, in order to avoid their own economic interests from loss, are motivated to keep the agency cost minimum, they will take the initiative to provide to the client company's performance and operating conditions, can let the client feel its performance and the ability of information, make the client trust yourself and thus reduce agency cost, improve the expected reward agent. When the mandatory information disclosure cannot meet the client's needs, voluntary information disclosure becomes a necessity, and plays a positive role in reducing agency cost.

\subsubsection{Signal Transmission Theory}

In the securities market, investors can't get the full information of the securities and can't distinguish the company's advantages and disadvantages, so they can measure the value of all companies at an average price. Companies that have good news, to avoid being undervalued and unable to make a profit, send positive signals to the market to distinguish themselves from other companies, thus making the transaction successful.

According to the theory of signal, the company's managers have a lot of information, in order to make the outside investors will also be able to understand the real value of enterprises and rationally to price securities issued by companies to make the company get good development opportunities, managers only through proper mechanism to send signals to the market. Good quality of listed companies in order to demonstrate its strength or suggests that the company's 
stock price is low, often the initiative to disclose some information is not mandatory, to transfer the relevant enterprises to actively for the market development of signal accurately. Investors through the full and reliable information, can make a judgment about the company's future, offer to buy shares in the company, at a higher price to get the correct evaluation company's market value. Accordingly, the poor performance or overvalued shares companies, in order to improve the relationship with investors, avoid investors about their suspicion and mistrust, also can through the voluntary disclosure of relevant information, to reflect some of the company's operating conditions. Therefore, the transmission of securities market signals can distinguish the quality of the company and its stock, and also strengthen the incentive for listed companies to voluntarily disclose information.

\subsubsection{Information Asymmetry Theory}

In the stock market, there is an information asymmetry between the company and the various investors. There is a large amount of information within the company, which tends to be in a favorable position, and outside investors can get limited information, so they are in a bad position.

According to the theory of asymmetric information, the company's internal management more than outside investors understand all kinds of information about the company, they directly involved in the day-to-day operation and management, can be more comprehensive, more accurately grasp the company now and the future of some of the information, through these information advantage can obtain additional economic benefits. The information obtained by outside investors is only part of the information of the company. It is often unable to judge the quality of the information and cannot accurately assess the value of the company. As a result of the existence of information asymmetry, investors in order to protect their own economic interests, will reduce the price of willing to pay to buy shares, and demand a higher risk compensation, compensation for investment so that the company's financing activities more difficult and lead to higher cost of capital. In order to solve this problem, the company management will be a voluntary disclosure of relevant information, motivation and pressure by reducing information asymmetry and increase investors' trust, to enhance the financing ability and reduce the cost of capital.

\subsection{Empirical Study of Voluntary Disclosure and Corporate Performance}

In the case of obeying the law, most of the differences between the mandatory disclosure of information of listed companies is small, the voluntary disclosure of information on the content, way, time, etc. with independent selective, so scholars in the study, discusses the information disclosure of related thesis under the background of more attention in the study of voluntary disclosure of information. 


\subsubsection{Domestic Research Review}

When discussing voluntary information disclosure, domestic scholars mainly focus on disclosure motivation, disclosure content and relationship research with related factors. In the study of the relationship between voluntary information disclosure and company performance, Zhang Zongxin et al. (2005) from 1998 to 2003 examined the validity of voluntary information disclosure behavior of listed companies [8]. The relationship between earnings performance and voluntary disclosure of listed companies in China was analyzed in 2002 by Feng Sixian (2005) and Yin Feng (2006) [9]. Xiao Hua fang and Yuan Jianguo (2007) tested the impact of the company's characteristics on voluntary information disclosure in 2002 data [10]; Liu Wei and Liu Xing (2008) selected Shanghai 2004 manufacturing companies as samples to examine the relationship between voluntary disclosure and corporate value of listed companies [11]. Han Haiwen and cui gang (2009) discussed the relationship between accounting information quality and voluntary disclosure in listed companies from 2005 to 2007 [12]. The study to a similar conclusion: voluntary information disclosure of listed companies in our country and the company's performance has significantly positive correlation, good efficiency and high profitability of listed companies are more likely to voluntarily disclose information. Wu Shengzhu column (2007) used the data of 1185 sample companies to analyze the influence factors of voluntary information disclosure, found the extent of voluntary disclosure of the annual report of the listed companies in China and profitability, there is no significant relationship [13]; Liu Guoliang and Chang Yanli (2008) tested the quality of voluntary information disclosure of listed companies in 2006, and found that the relationship between profitability and voluntary disclosure quality was not obvious [14]. Liu Wenjun and Mi Li (2008) were randomly selected from Shenzhen the 88 listed companies in 2005 annual report disclosure situation as the research sample, the quality of accounting information of listed companies and the relationship between voluntary disclosure, the same conclusion [15]. Overall, the domestic academic research on voluntary information disclosure of listed companies is still not enough systemic (Sun Yafeng, 2011) [16], fully explore all kinds of variables impact on voluntary information disclosure level will be the direction of further research in the future.

\subsubsection{Foreign Research Review}

Western scholars research mainly problems of voluntary information disclosure of listed companies can be summarized as the following areas: one is the countries or regions listed companies voluntary information disclosure content of classified and comparative analysis; Second, intrinsic motivation of voluntary disclosure of information research, individuality demand, financing motivation, risk aversion, strengthening control and aspiration for arbitrage is considered to promote the company voluntary disclosure of positive factors; Third, the research on the influence factors of voluntary information disclosure, and the relevant research conclusions in this field are more diverse and different. Four is 
the study of the economic consequences of voluntary disclosure, and scholars have found that voluntary information disclosure has great influence on assisting in analysis, stimulating stock price, advancing decision making, and strengthening prediction. Specific to the proposition that this article concern, sealing demand (2005) found that "when the relationship between company performance and the voluntary disclosure, western scholars to the conclusion that there is a big differences" [9], according to the principal-agent theory, the performance good management to ensure the interests tend to voluntarily disclose more information, but also support good company will is based on the theory of signal to distinguish with bad company and reduce market uncertainty or misunderstanding have more information disclosure and voluntary, but the existing empirical research conclusion is not unanimous support above statement, but there are certain differences.

Some scholars research results support the relationship between the performance positively related to the voluntary disclosure of information, such as Forker (1992) on the Toronto stock exchange 80 biggest listed companies to research has shown that good results will promote the voluntary disclosure of listed companies more information [17]; Lang and Lundholm FAF (1993), according to a 1985 1993 scores about the company's information disclosure, to study the influence factors of voluntary disclosure of enterprise, the empirical results also show that the performance more good companies voluntary information disclosure rating is higher [18]; Raffournier (1995) further research on the listed companies in Switzerland reveals that the degree of voluntary disclosure of financial information is positively correlated with the company's profit [19]; Abe and Chung (2009) demonstrate in Japan that management will actively disclose information due to the concerns of creditors [20]; Dhaliwal et al. (2011) also found that publicly listed companies that voluntarily disclose information effectively reduce the cost of equity capital and are potential performance gains [21].

But there are not consistent with theoretical analysis research, such as Mc Nally (1982) in New Zealand listed companies results show that the surplus earnings will not affect the degree of voluntary information disclosure [22]; Cowen, etc. (1987), also stressed that high profitability is not more than the low margins company voluntary disclosure of social responsibility information [23]; Hossain (2009) study of the listed company of Qatar also pointed out that profit performance variables such as no significant impact on voluntary information disclosure level [24].

Through combing of important academic literature at home and abroad, the author found that scholars of voluntary information disclosure and corporate business performance of the relationship between the contrary research conclusion, different enterprises in different situation on information disclosure of coping strategies and gambling behavior is complicated, academe has not yet cannot agree in this field, in stages, divisions and even points area needs to follow up and analysis. 


\section{Study Design}

\subsection{Sample Selection}

Since most scholars focus on the hotel tourism listed companies and scenic spot tourism listed companies, less study pay attention to thematic tourism listed companies. This article chooses thematic tourism listed companies to deepen the research scope of listed tourism companies. In this paper, 11 companies have been selected for the study of the financial annual report published since the listing of 11 companies (Table 1). They have obtained 81 samples from 11 companies. The information disclosure data of this paper comes from the financial annual report disclosed by the various themed travel listed companies of the great tide information network. Tide of information network is the China securities regulatory commission designated website information disclosure of listed companies. It was founded in 1995, and it is the first domestic professional securities information website, at the same time it is also the first domestic full disclosure deep Shanghai more than 2500 listed companies announced large securities professional website information and market data.

\subsection{Variable Design}

\subsubsection{Dependent Variable-Voluntary Information Disclosure Index}

The level of voluntary disclosure includes the reliability, relevance and timeliness of information disclosure. Measuring about voluntary information disclosure of listed companies, the practice of foreign scholars mainly has two kinds: one is to use professional rating agencies (such as the American association for the study of investment management and AIMR) released the voluntary disclosure of information of rating as a result, the second is the researchers to build a voluntary

Table 1. The sample company.

\begin{tabular}{cccc}
\hline Stock code & Company name & Listing location & Date of the annual report \\
\hline 000069 & OCT A & Shenzhen stock exchange & $2001-2014$ \\
002159 & Sante & Shenzhen stock exchange & $2007-2015$ \\
002558 & Century Cruise & Shenzhen stock exchange & $2010-2014$ \\
002707 & UTour & Shenzhen stock exchange & $2013-2014$ \\
002059 & Yunnan Tourism & Shenzhen stock exchange & $2006-2014$ \\
300144 & Songcheng Performance & Shenzhen stock exchange & $2010-2015$ \\
300123 & SUNBIRD & Shenzhen stock exchange & $2010-2014$ \\
300178 & TEMPUS GLOBAL & Shenzhen stock exchange & $2010-2014$ \\
600593 & Sunasia & Shanghai stock exchange & $2002-2015$ \\
600555 & NINE DRAGON & Shanghai stock exchange & $2006-2014$ \\
600706 & QJCT & Shanghai stock exchange & $2012-2014$ \\
\hline
\end{tabular}

Notes: From the tide of information network. 
information disclosure index, such as Meek, Roberts and Gary (1995), Botosan (1997) and Chau and Gary (2002) and others research on voluntary disclosure of information is based on the construction of voluntary information disclosure index and the team itself [1].

At present, most Chinese scholars draw lessons from foreign relatively mature voluntary information disclosure index evaluation method, build the evaluation system of the voluntary disclosure of information, the literature confirms that this evaluation method is effective. In the research of listed tourism companies voluntary information disclosure, Shi Xiaoyan, Liu Haiying (2012) established index system of voluntary disclosure of information is relatively mature, so in this paper, by using this evaluation system, including strategic target, financial information and non-financial information indicators three categories, divided into 18 small classes, 26 items (Table 2) [25].

When calculating voluntary disclosure scores, the weights of voluntary disclosure indicators are not distinguished. If a sample company discloses a message, it will get one point. If not disclosed, the score is 0 , total score of 26 points. Such a design main consideration lies in the following two points: on the one hand, the choice of weight through qualitative evaluation, with very strong subjectivity, voluntary information disclosure index does not exist pare to improvement; Established by the author, on the other hand, research Angle facing is not a specific user of the annual report, but all users, the various indicators of the importance of the different with users, and it will be difficult to determine the weight. "Foreign studies have shown that given weights to different information disclosure project, sometimes the result deviates from the real situation, and the importance of individual projects in different periods are changing, all of this makes your project with weight subjective and cannot be beneficial conclusions” (Li Huiyun, et al., 2010) [26]. this supplementary evidence, some empirical studies abroad, such as Chow (1987) [27] and Botosan (1997), etc. [28], found to enactment right heavy and enactment right at the same time under the two paths of information disclosure index, can be found on the basis of two sets of index system to carry out the research will not change because of the different of weight, almost no effect, the result of the final conclusions are also similar. To build the related system which is the basis of the voluntary disclosure of information content system, guidelines, standards will with the improvement of the capital market constantly revised, so the voluntary information disclosure forms of evaluation index should be adopted to eliminate the impact of these changes, help to strengthen its tracking, comparison and analysis, strengthen the results of application reference value. Based on Meek (1995) [1], this paper uses the voluntary information disclosure index calculation method. The formula is:

Voluntary disclosure index (VDI)

Score of company's voluntary information disclosure

Total number of voluntary information disclosure index system 
Table 2. Voluntary information disclosure index system.

\begin{tabular}{|c|c|c|}
\hline $\begin{array}{l}\text { Indicators } \\
\text { category }\end{array}$ & $\begin{array}{l}\text { Specific } \\
\text { indicators }\end{array}$ & Entry \\
\hline \multirow{13}{*}{$\begin{array}{l}\text { Strategic } \\
\text { index }\end{array}$} & Business & $\begin{array}{l}\text { 1) Development status and changing trends of } \\
\text { macro-economic aspects related to the business of the company }\end{array}$ \\
\hline & environment & $\begin{array}{l}\text { 2) The development status and trend of the external operating } \\
\text { environment related to the company's business }\end{array}$ \\
\hline & Company status & 3) The company's industry status or regional market position \\
\hline & \multirow{4}{*}{$\begin{array}{l}\text { Development } \\
\text { strategy }\end{array}$} & $\begin{array}{l}\text { 4) The company's development direction, development } \\
\text { planning, competitive strategy and management policy, etc. }\end{array}$ \\
\hline & & 5) The main advantages of the company \\
\hline & & 6) Difficulties with the company \\
\hline & & 7) Enterprise culture construction \\
\hline & \multirow{3}{*}{ Prospect forecast } & 8) The impact of strategy on current performance \\
\hline & & 9) The impact of strategy on future performance \\
\hline & & $\begin{array}{l}\text { 10) The continuity and stability of the company's operation } \\
\text { and profitability }\end{array}$ \\
\hline & Risk tip & $\begin{array}{l}\text { 11) Reveal to the company's future development strategy and } \\
\text { business objectives of an adverse effect on the implementation } \\
\text { of all risk factors (including macro policy risk, market or } \\
\text { business management risk, financial risk, technology risk, etc.) }\end{array}$ \\
\hline & Business plan & $\begin{array}{l}\text { 12) The listed company will introduce the countermeasures } \\
\text { and measures that have been (or proposed) according to the } \\
\text { actual situation. The countermeasures and measures should be } \\
\text { specific and operable }\end{array}$ \\
\hline & $\begin{array}{l}\text { The main } \\
\text { business }\end{array}$ & 13) Market changes in major businesses (for reasons of change) \\
\hline \multirow{7}{*}{$\begin{array}{l}\text { Financial } \\
\text { information } \\
\quad \text { index }\end{array}$} & Operating cost & $\begin{array}{l}\text { 14) Changes in the composition of operating costs (for reasons } \\
\text { of change) }\end{array}$ \\
\hline & $\begin{array}{l}\text { Production and } \\
\text { marketing } \\
\text { situation }\end{array}$ & $\begin{array}{l}\text { 15) Market share status (to explain the reasons for change) } \\
\text { Intangible assets }\end{array}$ \\
\hline & Intangible assets & $\begin{array}{l}\text { 16) Unrecognized intangible asset information that is of vital } \\
\text { importance to the company's success }\end{array}$ \\
\hline & \multirow{4}{*}{$\begin{array}{l}\text { Financial } \\
\text { forecasting } \\
\text { information }\end{array}$} & 17) Profit forecast for the New Year \\
\hline & & 18) Capital expenditure forecast \\
\hline & & 19) Sales or turnover forecasts \\
\hline & & 20) Forecast of cash flow \\
\hline \multirow{6}{*}{$\begin{array}{l}\text { Non-financial } \\
\text { information } \\
\text { index }\end{array}$} & Equipment use & 21) The utilization of fixed assets (equipment) of the company \\
\hline & $\begin{array}{l}\text { Employee } \\
\text { information }\end{array}$ & $\begin{array}{l}\text { 22) Employee information: including employee' health and } \\
\text { safety, raining employees, employee performance assessment, } \\
\text { placement of unemployed employees, other benefits and other } \\
\text { information of employees }\end{array}$ \\
\hline & $\begin{array}{c}\text { Product } \\
\text { development }\end{array}$ & $\begin{array}{l}\text { 23) Research and development of new products or new } \\
\text { technologies }\end{array}$ \\
\hline & $\begin{array}{l}\text { Corporate } \\
\text { governance }\end{array}$ & 24) Self-evaluation report of internal control \\
\hline & $\begin{array}{l}\text { The social } \\
\text { responsibility }\end{array}$ & $\begin{array}{l}\text { 25) To perform the social responsibility, including in the public } \\
\text { mind setting up enterprise good image information, such as the } \\
\text { scope of expanding employment, maintenance worker rights } \\
\text { and interests and to participate in social activities such as social } \\
\text { responsibility }\end{array}$ \\
\hline & $\begin{array}{l}\text { Environmental } \\
\text { protection }\end{array}$ & $\begin{array}{l}\text { 26) Environmental protection and related information of } \\
\text { sewage charges, green fees and flood fund fees }\end{array}$ \\
\hline
\end{tabular}




\subsubsection{Independent Variable-Corporate Performance Indicators}

The performance of the company is a comprehensive index which is influenced by a variety of factors. The evaluation of the performance of tourism listed companies should not only adopt one index, but the application of a set of indicators to reflect comprehensively. In this paper, the implementing rules for the central enterprise integrated performance evaluation for reference, adopt reflect the profitability of listed tourism companies a certain period, asset quality, debt risk and the financial indicators of business growth, return on net assets, total assets turnover ratio, asset-liability ratio and operating income growth rate as an alternative indicator of a company's accounting.

\subsection{Research Hypothesis}

Based on the market signal theory, the higher the return on equity, the company's "good news" the more, the listed company to investors are more willing to pass on more information, to help investors to estimate the value of the company and make a optimistic expectations. Therefore, it is a good idea to assume the good image of the company with good performance and high profitability, so as to show its good image to the shareholders, it will be willing to voluntarily carry out the higher level of information disclosure. Based on the above theories, this paper puts forward hypothesis 1 :

H1: The return on equity of thematic tourism listed companies is positively correlated with the level of voluntary information disclosure.

Total asset turnover is a measure of theme class tourist asset quality and management level of important indicators of listed companies, company managers higher operating efficiency and degree of diligence on operating efficiency of the company's assets will produce positive promoting effect, in the process of this positive improve management are also more motivated to disclose high quality information to set up good market image, thus the author assumes that the positive correlation. Based on the above theories, this paper puts forward hypothesis 2:

$\mathrm{H} 2$ : The total asset turnover rate of thematic tourism listed companies is positively correlated with the level of voluntary information disclosure.

Asset-liability ratio is reflecting the theme class tourism an important index of the capital structure of listed companies, can reflect the enterprise debt burden level and the degree of financial risk, some scholars think that the quality of the information disclosure of companies compared to the low quality of information disclosure of companies with lower asset-liability ratio (Tu Jianming, 2009) [29], so the asset-liability ratio is higher, the voluntary information disclosure level is lower. But also some people think that according to agency theory, because of the high risk and high asset-liability ratio of company need to take more supervision cost, due to the information disclosure can reduce the supervision cost, high financial leverage coefficient of the company leads to a higher level of voluntary disclosure of information, such as Hossain (1995) study confirms that "financial leverage coefficient and the level of disclosure is significantly positive- 
ly related to" [24]. In addition, there is also a empirical study found that the asset-liability ratio does not affect the information disclosure levels (Liu Rui, 2009) [30], company asset-liability ratio and liquidity ratio and the authority of the audit institutions does not significantly affect voluntary information disclosure level (Xiao Huafang, 2007; Wallace, et al., 1994) [10]. Considering the Chinese firms tend to hide the negative information, polish performance, thus make the asset-liability ratio is negatively related to the voluntary information disclosure level of hypothesis, to examine the relationship between the expression of theme class tourism listed companies. Based on the above literature, this paper puts forward hypothesis 3:

H3: The asset-liability ratio of thematic tourism listed companies is negatively correlated with the level of voluntary information disclosure.

The growth rate of operating income is an indicator of the growth of enterprises, and the growth of the enterprises with good growth has a good long-term development prospect. In order to enhance corporate image and show the potential of enterprises, high-growth enterprises tend to enhance market confidence through voluntary disclosure. Therefore, it is assumed that the growth rate of operating income of the listed companies is positively correlated with the degree of voluntary information disclosure. On this basis, this paper puts forward hypothesis 4 :

H4: The growth rate of operating income of thematic tourism listed companies is positively correlated with the level of voluntary information disclosure.

\subsection{Model Building}

The voluntary disclosure index is the dependent variable. The indicators that reflect the company's performance are the independent variables. Constructing multiple regression equation:

$$
V D I=\alpha+\beta 1 \mathrm{ROE}+\beta 2 \text { Totassrat }+\beta 3 \text { Dbastrt }+\beta 4 \text { Opeincmgrrt }+\varepsilon
$$

In the regression equation, $\alpha$ is a constant term, $\beta i$ is the coefficient that explains the variable $(i=1, \cdots 7), \varepsilon$ is the random error term, and the variables are defined as Table 3.

\section{Research Results and Discussion}

\subsection{Descriptive Statistical Analysis}

\subsubsection{Analysis of Voluntary Disclosure Level}

This paper uses SPSS 19.0 software to conduct empirical research of thematic tourism listed companies' voluntary information disclosure and performance. The Table 4 shows that thematic tourism listed companies voluntary information disclosure level the overall average, although the voluntary information disclosure index, lowest 0.38 , but up to 0.77 , and the mean value of 0.6087 . It can be seen that the voluntary information disclosure level of the listed companies is relatively high, and the information disclosure system is relatively perfect. 
Table 3. Definitions of the research variables.

\begin{tabular}{|c|c|c|c|}
\hline Category & The variable name & Variable code & Variable description \\
\hline $\begin{array}{l}\text { Dependent } \\
\text { variable }\end{array}$ & $\begin{array}{c}\text { Voluntary disclosure } \\
\text { index }\end{array}$ & VDI & $\begin{array}{l}\text { Evaluate the level of voluntary disclosure of } \\
\text { travel listed companies }\end{array}$ \\
\hline \multirow{4}{*}{$\begin{array}{l}\text { Independent } \\
\text { variables }\end{array}$} & Return on Equity & ROE & $\begin{array}{l}\mathrm{ROE}=\text { net profit } * 2 / \text { (initial shareholder } \\
\text { equity }+ \text { final shareholder's equity) } \times 100 \%\end{array}$ \\
\hline & $\begin{array}{l}\text { Turnover of Total } \\
\text { Assets }\end{array}$ & Totassrat & $\begin{array}{l}\text { Totassrat }=\text { (operating income/average } \\
\text { assets) }{ }^{\star} 100 \%\end{array}$ \\
\hline & Debt to Asset Ratio & Dbastrt & Dbastrt $=($ total liabilities/assets $) \times 100 \%$ \\
\hline & $\begin{array}{l}\text { Operating Income } \\
\text { Growth Rate }\end{array}$ & Opeincmgrrt & $\begin{array}{l}\text { Opeincmgrrt }=\text { (current operating } \\
\text { income/operating income from the same } \\
\text { period last year) }{ }^{*} 100 \%\end{array}$ \\
\hline
\end{tabular}

Notes: From the "Implementation rules for comprehensive performance evaluation of central enterprises".

Table 4. Descriptive statistical results of voluntary disclosure index.

\begin{tabular}{ccccc}
\hline Minimum & Maximum & Mean value & The standard deviation & Number of samples \\
\hline 0.38 & 0.77 & 0.6087 & 0.11867 & 81
\end{tabular}

Notes: From this article.

Through one by one through theme class tourism the annual financial report of listed companies in China, while sample companies can be found in the announcement has a voluntary disclosure of information, but disclosure level difference is bigger, disclosure content focuses on the strategic index and non-financial information index, index disclosure of financial information. Most samples revealed operating environment, the company status, company development strategy, business plan, product development, etc., this is helpful for investors to understand company's future development, also reflects the good mentality for the development of the company focus on the long term, but "the good news about" the vision of description is more, closely in combination with the practical situation of enterprise information also need to strengthen. More samples revealed the development strategy of the company (mainly the company's development direction, development planning, competitive strategy and business policy, etc.), risk warning, financial forecast information (mainly the profit forecast), corporate governance, such as information, can give investors more specific enterprise management situation analysis, especially the development and competition, policy, risk, profit and internal control of the more important information, appear more valuable.

Company's main advantages, problems, the development strategy of information such as the enterprise culture construction and equipment use, employee information, social responsibility, environmental protection and so on disclosure of information is less, few companies disclose the outlook, the main business, operating cost, production and marketing situation, intangible assets and other information. Company's main advantages, problems, enterprise culture construction, the lack of social responsibility, environmental protection infor- 
mation should not be, on the one hand, the conditions of the enterprise shall, on its own development there is a sober understanding, on the other hand, the enterprise culture, social responsibility and environmental protection responsibility set of far-reaching significance for the enterprise image, the lack of the above information will restrict enterprises. As for the outlook and the financial forecast information, there are not predict risk, if the deviation is too much, there will be to cause investors decision-making errors, and may also brings the risk of litigation to the listed company, so for this kind of information disclosure of listed companies is very cautious.

\subsubsection{Analysis of Annual Voluntary Disclosure Level}

From the time series analysis, the averaged annual voluntary information disclosure index, and according to its results do line chart (Figure 1), the average of voluntary information disclosure index from 0.38 in 2001 to gradually rose to 0.74 in 2015 , showing a rising trend year by year, so our theme class tourism company boss to the rising number of voluntary information disclosure, information disclosure system is gradually perfect.

\subsection{Correlation Analysis}

From the disclosure of 81 samples (Table 5), voluntary information disclosure index under the $5 \%$ significant level is only related to the total asset turnover is, positively related to the growth rate of return on net assets, operating income (not significant), and negatively related to the asset-liability ratio (not significant).

\subsection{Regression Analysis}

In this paper, using SPSS18.0 statistical software for 81 samples of disclosure situation has carried on the multiple linear regression, the regression equation of statistical results and the related test are shown in Table 6, adjusted $\mathrm{R}^{2}$ is 0.117 , hat explanation variable the explanation power of voluntary information disclosure index is $11.7 \%$. F value is 3.659 , the $1 \%$ significant level significantly, and that theme class tourism listed companies voluntary information disclosure

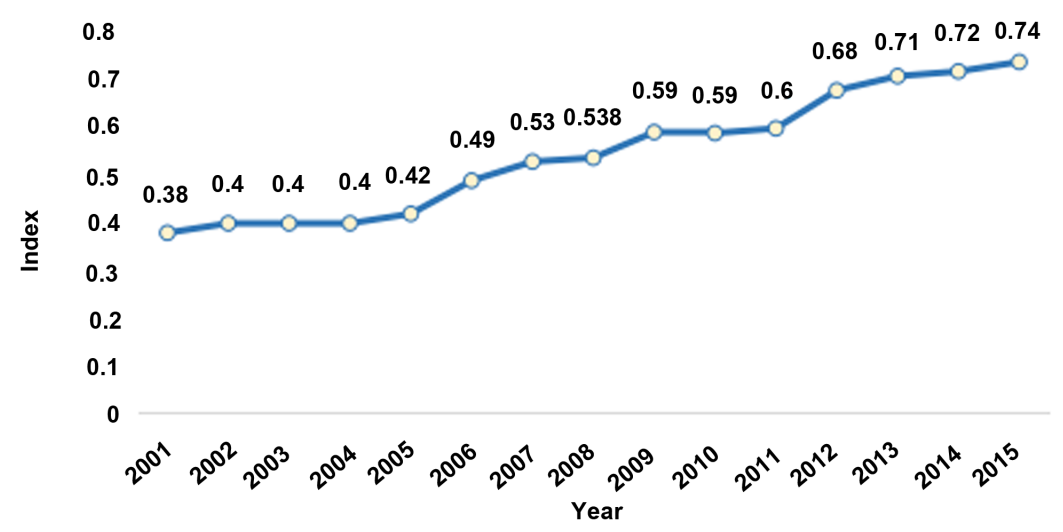

Figure 1. Annual voluntary disclosure level. Notes: From this article. 
Table 5. The simple correlation coefficients and significant horizontal tables between variables.

\begin{tabular}{cccccc}
\hline & $\begin{array}{c}\text { Return on } \\
\text { Equity }\end{array}$ & $\begin{array}{c}\text { Operating } \\
\text { Income } \\
\text { Growth Rate }\end{array}$ & $\begin{array}{c}\text { Turnover of } \\
\text { Total Assets }\end{array}$ & $\begin{array}{c}\text { Debt to Asset } \\
\text { Ratio }\end{array}$ & $\begin{array}{c}\text { Voluntary } \\
\text { disclosure } \\
\text { index }\end{array}$ \\
\hline $\begin{array}{c}\text { Return on Equity } \\
\text { Operating }\end{array}$ & 1 & & & & \\
$\begin{array}{c}\text { Income Growth } \\
\text { Rate }\end{array}$ & $0.268^{* *}$ & 1 & & & \\
$\begin{array}{c}\text { Turnover of Total } \\
\text { Assets }\end{array}$ & $0.234^{* *}$ & $0.239^{* *}$ & 1 & & \\
$\begin{array}{c}\text { Debt to Asset } \\
\text { Ratio }\end{array}$ & 0.094 & 0.044 & 0.042 & 1 & \\
$\quad \begin{array}{l}\text { Voluntary } \\
\text { disclosure index }\end{array}$ & 0.040 & 0.092 & $0.367^{* *}$ & -0.044 & 1 \\
\hline
\end{tabular}

Notes: From this article. ${ }^{* *}$ : indicates that it is significant at $5 \%$ level.

Table 6. Multiple regression results.

\begin{tabular}{|c|c|c|c|c|c|c|c|}
\hline \multirow{2}{*}{ Model } & \multicolumn{2}{|c|}{$\begin{array}{c}\text { Non-standardized } \\
\text { coefficient }\end{array}$} & \multirow{2}{*}{$\begin{array}{c}\begin{array}{c}\text { Standard } \\
\text { coefficient }\end{array} \\
\text { Beta }\end{array}$} & \multirow[b]{2}{*}{$\mathrm{t}$} & \multirow[b]{2}{*}{ Sig. } & \multicolumn{2}{|c|}{ Total linear statistics } \\
\hline & B & $\begin{array}{l}\text { Standard } \\
\text { error }\end{array}$ & & & & Tolerance & VIF \\
\hline Constant & $0.572^{\star *}$ & 0.033 & & 17.276 & 0.000 & & \\
\hline Return on Equity & 0.015 & 0.012 & 0.132 & 1.240 & 0.219 & 0.967 & 1.304 \\
\hline $\begin{array}{l}\text { Operating Income } \\
\text { Growth Rate }\end{array}$ & 0.002 & 0.003 & 0.067 & 6.36 & 0.527 & 0.992 & 1.008 \\
\hline $\begin{array}{c}\text { Turnover of Total } \\
\text { Assets }\end{array}$ & 0.195 & 0.061 & $0.340^{\star}$ & 3.194 & 0.002 & 0.974 & 1.026 \\
\hline Debt to Asset Ratio & -0.056 & 0.064 & -0.093 & -0.874 & 0.385 & 0.981 & 1.019 \\
\hline Adjusted $\mathrm{R}^{2}$ & 0.117 & & & & & & \\
\hline $\mathrm{F}$ & $3.659^{* *}$ & & & & & & \\
\hline
\end{tabular}

Notes: From this article. ${ }^{* *}$ : represents significant at $1 \%$ level; ${ }^{*}$ : represents a significant level of $5 \%$.

index and all significant linear relationship between variables, the linear model is used to describe the relationship between them properly. The value of tolerance is close to 1 , the value of the variance expansion factor VIF is close to 1 , indicating that the multiplicity of the explanatory variables is weak. The regression results show that the turnover rate of total assets is positively correlated with the voluntary information disclosure of the subject class travel listed companies at a significant level of 5\%, which supports $\mathrm{H} 2$; The return on net assets, the growth rate of operating income and the voluntary information disclosure are positively correlated, supporting $\mathrm{H1}$ and $\mathrm{H} 4$, but the relationship is not significant; The asset-liability ratio is negatively correlated with the disclosure of voluntary information and supports $\mathrm{H} 3$, but the relationship is not significant.

\section{Conclusions and Enlightenments}

The study found that the overall level of voluntary information disclosure in 
China's tourism companies was at a moderate level and showed a trend of upward trend. This suggests that the listed tourism companies have realized the importance of voluntary information disclosure, have gradually through the voluntary disclosure of information to the wishes of the corporate social image, but how to get the information timely, correctly and comprehensively revealed is still a long way to go.

The results of this study further show that there is a certain correlation between the core index of tourism listed companies and voluntary disclosure. Return on net assets, total assets turnover, operating income growth rate and voluntary information disclosure is positively related to, this to a certain extent, verifies the relevant theories of the market signal theory, the voluntary disclosure of information more conducive to the public the right decisions, also is more conducive to the market through the efficient allocation of resources and become more effective. From the perspective of signal theory, good financial performance can prompt management to disclose high-quality information, while companies with poor financial performance may tend to avoid voluntary disclosure. Therefore, the efficient market hypothesis has laid a theoretical foundation for information disclosure system, information disclosure system is also considered to establish the foundation of effective capital market conditions, is the starting point of improving capital market efficiency. At the same time, tourism listed companies' voluntary information disclosure index is negatively related to the asset-liability ratio, namely the high quality of information disclosure of company compared with low quality of information disclosure has lower asset-liability ratio, and the conclusions are consistent with most scholars' point of view.

This paper further deepens the research on the impact of the performance of thematic tourism listed companies on voluntary information disclosure. In this paper, the theme class tourism listed company is the research object for the first time, which extends the research scope of tourism listed companies.

\section{Deficiencies and Prospects}

\subsection{Research Deficiencies}

Measure of voluntary disclosure of information quality should be evaluated from "authenticity, accuracy, completeness, timeliness, legal compliance and fairness in six aspects". In this paper, the relationship between information disclosure quality and corporate performance is only studied from the perspective of the content of voluntary information disclosure. While not considering the time of voluntary information disclosure, disclosure frequency and other factors, this paper was used to construct the voluntary disclosure index measure the quality of voluntary information disclosure of listed tourism companies have some limitations.

\subsection{Research Prospects}

It should be pointed out that, this article emphasizes the information disclosure 
quality and the relationship between the company's financial performance, and the other important aspects of the factors of corporate governance factors not taken into consideration in this study. Corporate governance is the institutional restriction and incentive management information disclosure management factors, considering the factors on the one hand can better dig deep institutional factors driving in the information disclosure management, this article does not be researched from the perspective of management disclosure motivation. Therefore, this study can further expand at these levels.

\section{References}

[1] Meek, G.K., Roberts, C.B. and Gray, S.J. (1995) Factors Influencing Voluntary Annual Report Disclosure by US, UK, and Continental European Multinational Corporations. Journal of International Business Studies, 26, 555-572. https://doi.org/10.1057/palgrave.jibs.8490186

[2] FASB (2001) FASB Issues Report on Voluntary Disclosures, Improving Business Reporting: Insights into Enhancing Voluntary Disclosures. Financial Accounting Standards Board. Status Report_Financial Accounting Standards Board, No. 333, 4.

[3] Shenzhen Stock Exchange (2003) Guidance on Investor Relations Management of Listed Companies in Shenzhen Stock Exchange. China Securities Journal, 2003/10/21(012).

[4] Jenson, M.C. and Meckling, W.H. (1976) Theory of the Firm: Managerial Behavior, Agency Costs and Ownership Structure. Journal of Financial Economics, 3, 305-360. https://doi.org/10.1016/0304-405X(76)90026-X

[5] Stephen Ross (1979) Disclosure Regulation in Financial Markets: Implications of Modern Finance and Signaling Theory. In: Edwards, F.R., Ed., Financial Regulation, Chapter 4, Mc Graw-Hill, Inc., New York, 177-202.

[6] Akerlof, G.A. (1970) The Market for Lemons: Quality Uncertainty and the Market Mechanism. Quarterly Journal of Economics, 84, 488-500. https://doi.org/10.2307/1879431

[7] Spence, M. (1973) Job Market Signaling. Quarterly Journal of Economics, 87, 355-374. https://doi.org/10.2307/1882010

[8] Zhang, Z.X., Yang, F. and Yuan, Q.H. (2007) Does the Quality Improvement of Listed Companies Improve Company Performance?-Empirical Evidence Based on the Shenzhen Listed Company in 2002-2005. Accounting Research, 10, 16-23.

[9] Feng, S.X. (2005) Empirical Research on the Disclosure of Company Performance and Voluntary Information. Economic Problems Exploration, 6, 89-93.

[10] Xiao, H.F. and Yuan, J.G. (2007) Empirical Research on the Degree of Voluntary Information Disclosure and Corporate Characteristics of Listed Companies. Fortune Monthly (Theory), 4, 2-5.

[11] Liu, W. and Liu, X. (2008) Research on the Impact of Voluntary Disclosure on Corporate Value. East China Economic Management, 5, 66-69.

[12] Han, H.W. and Cui, G. (2009) Accounting Information Quality and Voluntary Information Disclosure-Empirical Evidence from Shenzhen. Lanzhou University Journal, 10, 49-53.

[13] Wu, S.Z. (2007) Empirical Analysis of the Influencing Factors of the Annual Report of Listed Companies in China. Contemporary Finance, 8, 121-124.

[14] Liu, G.L. and Chang, Y.L. (2008) Empirical Study on the Quality of Voluntary In- 
formation Disclosure of Listed Companies. Industrial Economic Review, 1, 27-44.

[15] Liu, W.J. and Mi, L. (2008) Empirical Research on the Relationship between Accounting Information Quality and Voluntary Disclosure of Listed Companies. Journal of Inner Mongolia University of Finance and Economics, 2, 90-93.

[16] Sun, Y. (2011) Review of Voluntary Information Disclosure of Listed Companies. Economist, No. 10, 87-88.

[17] Forker, J.J. (1992) Corporate Governance and Disclosure Quality. Accounting and Business Research, 22, 111-124. https://doi.org/10.1080/00014788.1992.9729426

[18] Lang, M. and Lundholm, R. (1993) Cross-Sectional Determinants of Analyst Ratings of Corporate Disclosures. Journal of Accounting Research, 31, 246-271. https://doi.org/10.2307/2491273

[19] Raffournier, B. (1995) The Determinants of Voluntary Financial Disclosure by Swiss Listed Companies. The European Accounting Review, 4, 261-280. https://doi.org/10.1080/09638189500000016

[20] Abe, N. and Chung, Y. (2009) Voluntary Information Disclosure and Corporate Governance: The Empirical Evidence on Earnings Forecasts. Hitotsubashi Journal of Economics, 49, 165-180.

[21] Dhaliwal, D.S., Li, O.Z., Tsang, A., et al. (2011) Voluntary Nonfinancial Disclosure and the Cost of Equity Capital: The Initiation of Corporate Social Responsibility Reporting. Accounting Review, 86, 59-100. https://doi.org/10.2308/accr.00000005

[22] Mc Nally, G.M., Eng, L.H. and Hasseldine, C.R. (1982) Corporate Financial Reporting in New Zealand: An Analysis of User Preference, Corporate Characteristics and Disclosure Practices for Discretionary Information. Accounting and Business Research, 13, 11-20. https://doi.org/10.1080/00014788.1982.9729725

[23] Cowen, S., Ferreri, L. and Parker, L. (1987) The Impact of Corporate Characteristics on Social Responsibility Disclosure: A Typology and Frequency-Based Analysis. Accounting, Organizations and Society, 12, 111-122. https://doi.org/10.1016/0361-3682(87)90001-8

[24] Hossain, M. and Hammami, H. (2009) Voluntary Disclosure in the Annual Reports of an Emerging Country: The Case of Qatar. Advances in Accounting, Incorporating Advances in International Accounting, 25, 255-265.

[25] Shi, X., Liu, H. and Xu, F. (2014) Research on the Correlation between Voluntary Information Disclosure and Performance of Tourism Companies. Tourism Science, 4, 26-38.

[26] Li, H., Li, D. and Liu, J. (2010) Empirical Research on the Impact of Public Company Governance Structure on Voluntary Disclosure. Statistics and Information, No. 1, 78-83.

[27] Chow, C.W. and Wong-Boren, A. (1987) Voluntary Financial Disclosure by Mexican Corporations. Accounting Review, 62, 533-541.

[28] Botosan, C.A. (1997) Disclosure Level and the Cost of Equity Capital. The Accounting Review, 72, 323-349.

[29] Tu, J. (2009) Financial Performance Drives Management Information Disclosure-Empirical Evidence from Listed Companies. Management Review, 9, 86-93.

[30] Liu, R. and Li, J. (2009) Empirical Research on the Voluntary Disclosure and Shareholding Structure of Listed Companies in China. Journal of Yunnan University of Finance and Economics, 5, 88-97. 